\title{
Recerca a Secundària
}

\author{
Jordi Domènech Lizcano \\ President de MAGMA (Associació per Promoure la Recerca Jove) i estudiant de Físiques
}

\begin{abstract}
Al descobrir que ens ho podíem passar bé investigant, vàrem impulsar la creació, ara fa nou anys, de MAGMA, una associació juvenil que té com a prioritat difondre la recerca entre els joves.
\end{abstract}

En els últims anys, la ciència ha contemplat avenços en quasi tots els camps, la majoria inimaginables fa pocs anys. Actualment tothom és conscient que la investigació és importantíssima per al progrés d'una societat, ja que millora la qualitat de vida. La quantitat de despesa en recerca ha arribat a ser un potent indicador econòmic. Que lluny queden els dies del "que inventin els altres"!

\section{Recerca a Batxillerat... i a l'ESO}

Avui el fet d'investigar, de fer recerca, és molt més comú en la nostra societat. Si preguntéssim a la gent on creu que els estudiants entren en contacte directe amb la recerca, la majoria contestarien que a la Universitat, oblidant que des de la LOGSE, a Catalunya, és obligatori realitzar un treball de recerca per aconseguir el títol de Batxiller. Però el que la gran majoria de gent desconeix és que també és fa recerca a l'ESO i fins i tot abans.

Tot hi que no consta específicament en el currículum escolar, en diversos instituts s'anima i es guia als alumnes perquè portin a terme recerques al llarg dels quatre anys d'educació secundària obligatòria. Normalment és a instàncies d'algun professor a qui encara agrada la seva feina i que, cansat de veure com als alumnes només se'ns exigeix que memoritzem un llistat de fórmules, decideix fer-hi alguna cosa destinant-hi part del seu temps de classe i del seu temps lliure.

En contra d'aquesta pràctica he sentit diverses objeccions amb una cosa en comú: que els alumnes no estem preparats, que no som capaços de fer-ho.

Evidentment, una recerca realitzada per alumnes de secundària no tracta sobre temes de la mateixa fondària que la dels investigadors professio- nals ni guanyarà el Nobel. Però malgrat tot això, hi ha diverses raons a favor d'aquesta iniciativa:

- En primer Iloc, l'educació tradicional és poc pràctica, molt pautada, de manera que impedeix en bona mesura que els alumnes pensem per nosaltres mateixos i desenvolupem, no només l'imprescindible habilitat per resoldre problemes nous, sinó el desig d'anar més enllà, de saber més coses, l'esperit crític necessari per ser membres actius de la nostra societat.

- La recerca potencia la creativitat i la imaginació, qualitats que tenim de sobres quant som petits però que sembla que perdem a l'adolescència. Són dues armes molt poderoses quan intentem buscar solucions a tot allò que ens intriga. No és casual que molts grans científics hagin desenvolupat les seves teories de joves (Newton descobrí la gravetat als 23 anys; Einstein anunciava la teoria de la relativitat als 26).

- A més, si s'enfoca correctament, permet aprendre a treballar en equip i a espavilar-se sense esperar l'ajut del professorat. Per això la recerca té un component de superació personal. És un repte i, com a tal, comporta una injecció d'autoestima quan es supera que contrasta amb la monotonia amb que s'afronten la resta de deures.

Jo mateix he realitzat diverses recerques durat l'ESO i fins i tot he tingut la sort de poder ser el tutor de diversos treballs. I m'he adonat que, en general, als alumnes els agrada, arribant fins a l'extrem de quedar-se voluntàriament desprès de classe per poder treballar en el seu projecte. 


\section{L'associació MAGMA}

Aquest descobriment -que ens ho podíem passar bé investigant- va ser el que va impulsar la creació, ara fa nou anys, de MAGMA, una associació juvenil que té com a prioritat difondre la recerca entre els joves.

Per aconseguir aquest fi, MAGMA duu a terme diverses accions: assessora als centres sobre com tutorar treballs de recerca, fa xerrades, organitza tallers i, com a activitat essencial, organitza cada any l'Exporecerca Jove, una mostra oberta al públic de treballs de recerca realitzats per nois i noies d'entre 12 i 18 anys i que enguany arriba a la seva IX edició.

La mostra és singular: no és un congrés amb ponències, sinó una fira oberta a tothom on cada equip participant disposa d'un estand (4 plafons d'un metre d'amplària per 2 d'alçada, una taula i un parell de cadires) per exposar el seu treball. Un jurat format per persones de diverses disciplines, majoritàriament professorat, avaluen els treballs I concedeixen diversos premis, consistents en la participació en d'altres mostres similars que tenen lloc a l'estranger.

Però el més sorprenent de l'associació no és el caràcter singular de la mostra que organitzem sinó la gent que la compon: unes quantes dotzenes de joves entusiastes (amb l'aportació impagable d'alguns professors) que dediquem el nostre esforç i el nostre temps lliure a aquest projecte de forma altruista. 